\title{
PENGARUH PERBAIKAN METODE PEMBAGIAN BATANG TERHADAP WAKTU KERJA DAN PRODUKTIVITAS PENEBANGAN HUTAN ALAM PRODUKSI: STUDI KASUS DI PT. DWIMAJAYA UTAMA (The Effect of Bucking Method Improvement on Working Time and Felling Productivity in Natural Production Forest: A Case Study in PT. Dwimajaya Utama)
}

\author{
Soenarno \& Yuniawati \\ Pusat Penelitian dan Pengembangan Hasil Hutan \\ Jl. Gunung Batu No. 5, Bogor 16610 \\ Telp. (0251) 8633378, Fax. (0251) 8633413 \\ E-mail: soenarno@yahoo.co.id
}

Diterima 23 Juli 2018, direvisi 26 November 2018, disetujui 11 Februari 2019

\begin{abstract}
The improvement of bucking method in tree felling was examined to observe harvesting efficiency in natural production forest. This paper studies distribution of work time elements, productivity, and efficiency of timber utilization in accord with application of bucking system improvement. Research was conducted in natural forest production concession of PT. Dwima Jaya Utama in Central Kalimantan. The study was conducted using four research sample plots (PCP) measuring of $100 \mathrm{~m} \times 200 \mathrm{~m}$ which were placed intentionally (purposive) on selected cutting plots. Two PCPs were used for the conventional logging treatment $(C V)$ and the remaining plots were allocated for the improving stem distribution methods (IBM). Data analysis was performed statistically using PWSTAT version 23.0. Results showed that the CV method's working time of 14.6 minutes/tree was not significantly different with that of IBM working time of $15.5 \mathrm{~min} /$ tree. Wood utilization efficiency of IBM was 93.1\%, which was higher than that of the conventional method (CV) of $85.4 \%$. However, the productivity of IBM was $27.161 \mathrm{~m}^{3} /$ hour, which was lower than that of the CV method of $32.847 \mathrm{~m}^{3} /$ hour.
\end{abstract}

Keywords: Natural production forest, working time, logging, conventional, improvement, stem distribution

\begin{abstract}
ABSTRAK
Perbaikan sistem pembagian batang pada metode penebangan di hutan alam produksi perlu dilakukan agar penebangan dapat dilakukan lebih efisien. Tulisan ini mempelajari sebaran elemen waktu kerja, produktivitas, dan efisiensi pemanfaatan kayu hasil penerapan perbaikan sistem pembagian batang. Penelitian dilakukan di lokasi pengusahaan hutan alam produksi, PT. Dwima Jaya Utama, Kalimantan Tengah. Penelitian dilakukan pada empat plot contoh penelitian (PCP) berukuran $100 \mathrm{~m}$ x $200 \mathrm{~m}$ yang ditempatkan secara sengaja (purposive) pada petak tebang terpilih. Dua PCP untuk perlakukan penebangan konvensional dan yang lainnya untuk perbaikan metode pembagian batang. Analisis data dilakukan secara statistik menggunakan PWSTAT versi 23.0. Hasil penelitian menunjukkan bahwa waktu penebangan metode konvensional (CV) adalah 14,6 menit/pohon tidak berbeda nyata dengan perbaikan metode pembagian batang (IBM) sebesar 15,5 menit/pohon. Efisiensi pemanfaatan kayu IBM adalah 93,1\% lebih tinggi dibandingkan metode CV sebesar 85,4\%. Namun demikian, produktivitas IBM adalah $27,161 \mathrm{~m}^{3} / \mathrm{jam}$ lebih rendah dibandingkan metode CV sebesar $32,847 \mathrm{~m}^{3}$ / jam.
\end{abstract}

Kata kunci: Hutan alam produksi, waktu kerja, penebangan, konvensional, perbaikan, pembagian batang 


\section{PENDAHULUAN}

Penebangan pohon di hutan alam produksi umumnya dilakukan dengan sistem semi mekanis menggunakan gergaji rantai (chainsaw). Penebangan sebagai komponen dasar dalam pemanenan kayu (logging) mempunyai peranan penting karena mempengaruhi kelestarian hutan (Ghajar \& Naja, 2012). Menurut Forestry Training Centre Incorporated (2010), penebangan pohon adalah pemotongan pohon komersial yang sebelumnya dipilih dengan menggunakan teknik penebangan yang terarah. Satu regu tebang biasanya terdiri dari seorang operator chainsaw dan pembantu penebang (helper). Penebangan yang dilakukan secara benar dapat memaksimalkan volume dan kualitas produk kayu bulat serta biaya yang lebih rendah (Greulich, Hanley, McNeel, \& Baumgartner, 1999).

Kegiatan penebangan mencakup pembuatan takik rebah dan takik balas (undercut and backcut), pembagian batang (bucking), dan pemotongan bagian ujung (toping off) pohon (Abbasi, Lotfalian, \& Hosseini, 2013; Elias, 2016). Pada penebangan konvensional masih banyak meninggalkan limbah batang bebas cabang (BBC) maupun batang di atas cabang (BAC) sehingga efisiensi pemanfaatan kayu tidak maksimal. Beberapa hasil penelitian menunjukkan bahwa besarnya limbah BBC berkisar antara 14-40\% (Budiaman, 2002; Ruslim \& Gunawan, 2008; Matangaran, Partiani, \& Purnamasari, 2013; Soenarno, Endom, Basari, Dulsalam, Suhartana \& Yuniawati, 2016). Padahal, limbah tersebut secara teknis dapat diolah menjadi produk yang lebih bernilai, diantaranya untuk menghasilkan kayu gergajian dan bahan baku kayu lapis (Enters, 2001; Budiaman, 2002; Astana, Soenarno \& Endom, 2015).

Secara teknis, pemanfaatan kayu dapat dilakukan antara lain dengan memperbaiki metode pembagian batang (bucking method) dari yang sebelumnya dilakukan di petak tebang menjadi di tempat pengumpulan kayu sementara (TPn). Pembagian batang di TPn tersebut dilakukan setelah sortimen kayu bulat termasuk BAC diukur dan diuji (grading and scaling) oleh tenaga teknis bersertifikat pengelolaan hutan produksi lestari penguji kayu bulat rimba (Ganis PHPL-
PKBR). Perbaikan metode pembagian batang ini memerlukan tambahan pekerjaan di petak tebang berupa kegiatan pemotongan cabang (delimbing) branching) sampai diameter ujung batang minimal $30 \mathrm{~cm}$, sehingga menambah waktu kerja. Garland dan Jackson, (1997) menyatakan bahwa arah rebah dan pembagian batang yang benar akan meningkatkan kualitas dan mutu kayu hasil penebangan. Hal ini diperkuat pendapat Ward, (2011) bahwa keberhasilan penebangan sangat ditentukan oleh arah rebah dan keterampilan operator chainsaw di lapangan. Di lain pihak, mengingat kondisi pohon yang ditebang di hutan alam memiliki variasi ukuran diameter dan tinggi banir yang berbeda, maka diduga akan mempengaruhi waktu kerja penebangan. Tujuan dari penelitian ini adalah untuk menganalisis pengaruh diameter dan tinggi banir pohon yang ditebang, baik pada cara penebangan biasa maupun dengan sistem pembagian batang yang diperbaiki.

\section{BAHAN DAN METODE}

\section{A. Lokasi dan Waktu Penelitian}

Penelitian dilakukan pada bulan September 2017 di IUPHHK-HA PT. Dwimajaya Utama di Desa Tumbang Manggu, Kecamatan Sanaman Mantikei, Kabupaten Katingan, Provinsi Kalimantan Tengah. Secara geografis, areal PT. Dwimajaya Utama berada diantara $0^{\circ} 50^{\prime}$ 16"-1 ${ }^{\circ} 08^{\prime} 55^{\prime \prime}$ Lintang Selatan dan $112^{\circ} 39^{\prime}$ $11^{\prime \prime}-113^{\circ} 35^{\prime}$ 00" Bujur Timur. Kondisi topografi umumnya bergelombang dengan persentase kelerengan landai (85,02\%), agak curam $(10,52 \%)$, curam $(4,45 \%)$, dan sangat curam $(0,54 \%)$. Ketinggian areal minimum $\pm 50 \mathrm{~m}$ dan maksimum 400 mdpl.

\section{B. Bahan dan Alat}

Bahan yang digunakan dalam penelitian ini adalah meteran (50 $\mathrm{m}$ dan $8 \mathrm{~m}$ ), pengukur waktu, tali plastik, spidol, label plastik, cat, penggaris, dan kalkulator. Alat penebangan pohon yaitu gergaji rantai (chainsaw) dengan panjang batang pengantar (bar) rantai $70 \mathrm{~cm}$ dan traktor sarad (skidder). 


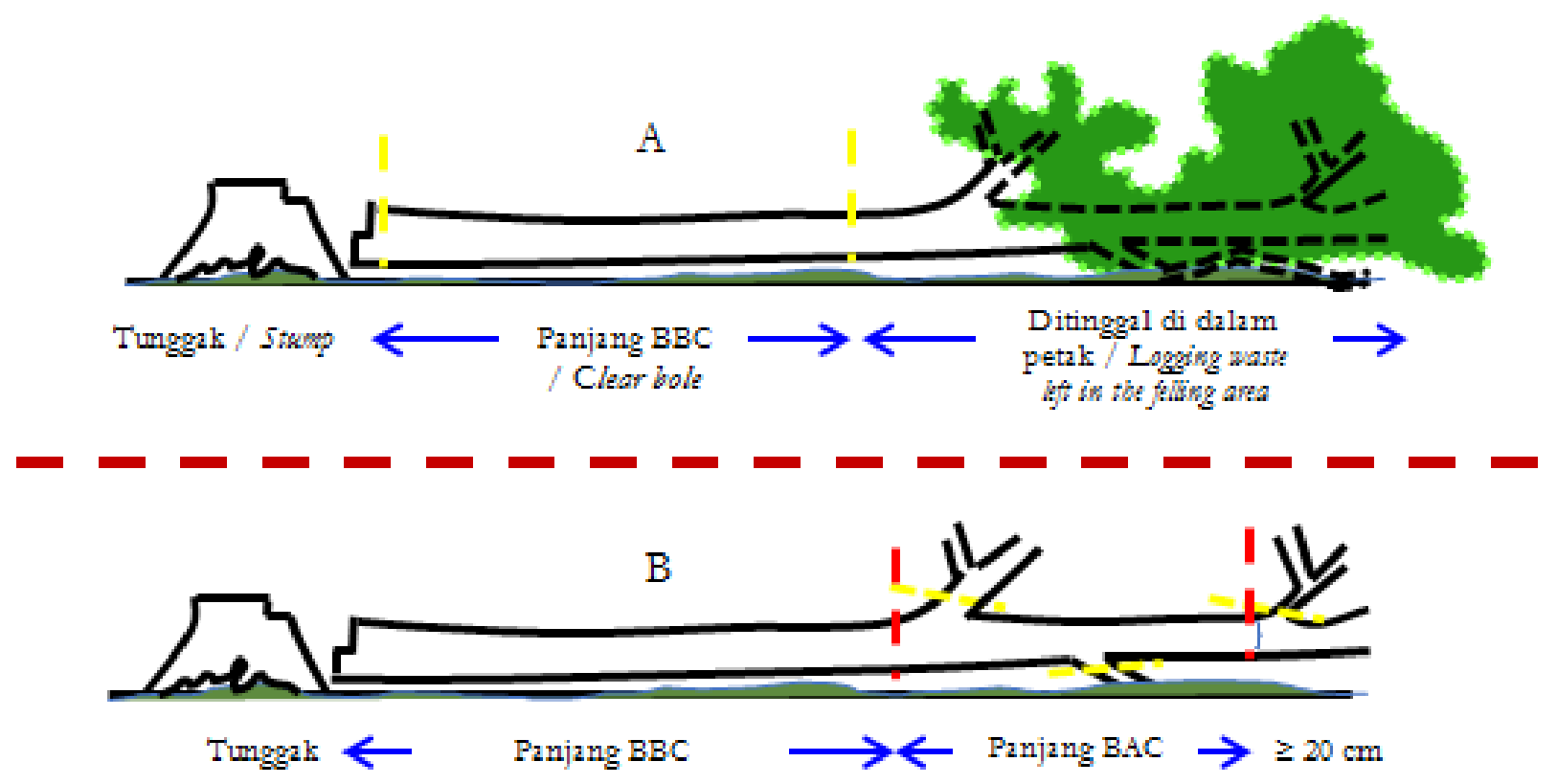

Keterangan (Remarks): $\quad \mathrm{BBC}=$ Batang bebas cabang (Clear bole $), \mathrm{BAC}=$ Batang di atas cabang $($ Upper stem of branch)

\section{Gambar 1. Perbedaan teknik penebangan konvensional (A) dan perbaikan sistem pembagian batang $(\mathrm{B})$ \\ Figure 1. Differences in conventional logging techniques $(A)$ and improvement of bucking systems $(B)$}

\section{Rancangan Penelitian dan Pengukuran Waktu Penebangan}

\section{Rancangan penelitian}

Penelitian dilakukan pada empat plot contoh penelitian (PCP) yang ditempatkan secara sengaja (purposive) pada petak tebang terpilih. Dua PCP dengan ukuran masing-masing $100 \mathrm{~m}$ x $200 \mathrm{~m}$ untuk teknik perlakuan penebangan konvensional sebagai kontrol dan dua PCP lainnya untuk teknik penebangan dengan perbaikan sistem pembagian batang. Metode penebangan konvensional adalah teknik penebangan seperti yang seharihari dilakukan operator chainsaw tanpa arahan dari peneliti dan pembagian batang dilakukan di petak tebang. Metode perbaikan pembagian batang adalah teknik penebangan seperti pada teknik konvensional tetapi terdapat kegiatan pemotongan cabang pohon (branching/delimbing) sepanjang batang utama di atas cabang (BAC) sampai minimal diameter $30 \mathrm{~cm}$ dan pembagian batang dilakukan di TPn setelah dilakukan pengukuran dan pengujian (grading scaling) oleh ganis PHPL-PKBR. Secara skematis perbedaan teknik penebangan konvensional dan perbaikan metode pembagian batang disajikan pada Gambar 1.

Penempatan PCP dilakukan dengan sengaja secara sistematik (purposive systematic sampling) pada petak tebang tahun 2017. Jarak PCP pertama dengan jalan angkutan antara 50-100 m sedangkan jarak antar PCP adalah $100 \mathrm{~m}$, seperti disajikan secara skematis pada Gambar 2.

\section{Pengukuran}

Jumlah pohon contoh pada metode penebangan konvensional sebanyak 17 pohon $\left(\mathrm{PCP}_{1}=9\right.$ pohon dan $\mathrm{PCP}_{2}=8$ pohon) sedangkan pada metode perbaikan pembagian batang sebanyak 18 pohon $\left(\mathrm{PCP}_{3}=11\right.$ pohon dan $\mathrm{PCP}_{4}=7$ pohon). Waktu penebangan pada masing-masing pohon contoh dilakukan dengan menggunakan metode kajian waktu kerja (time study). Pengukuran waktu penebangan dilakukan secara langsung dengan mengikuti pelaksanaan penebangan di lapangan baik di petak tebang maupun di TPn (Soenarno 


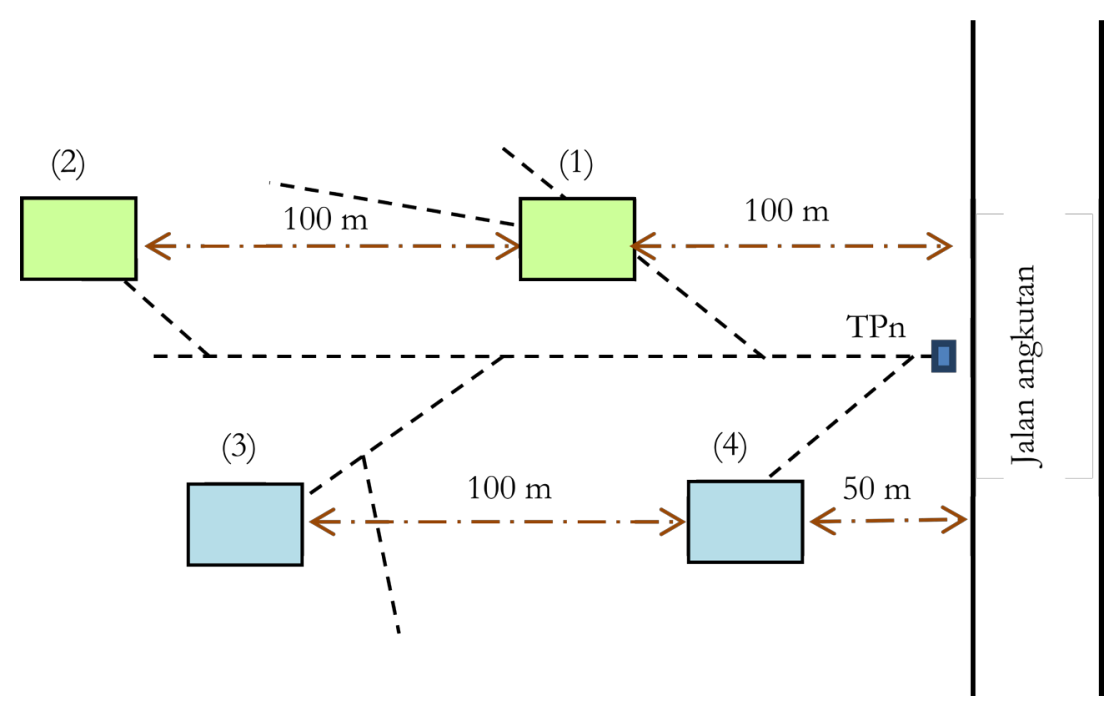

Keterangan (Remarks):

--- Jalan sarad (Skid road)

$\square=(1)$ \& (2) penebangan biasa (Ordinary felling)

$\square=(3)$ \& (4) perbaikan pembagian batang (Felling with improved bucking)

$\square=$ Tempat pengumpulan kayu sementara (Landing point, Tpn)

Gambar 2. Penempatan PCP di dalam petak tebang

Figure 2. The placement of sample plots in felling site

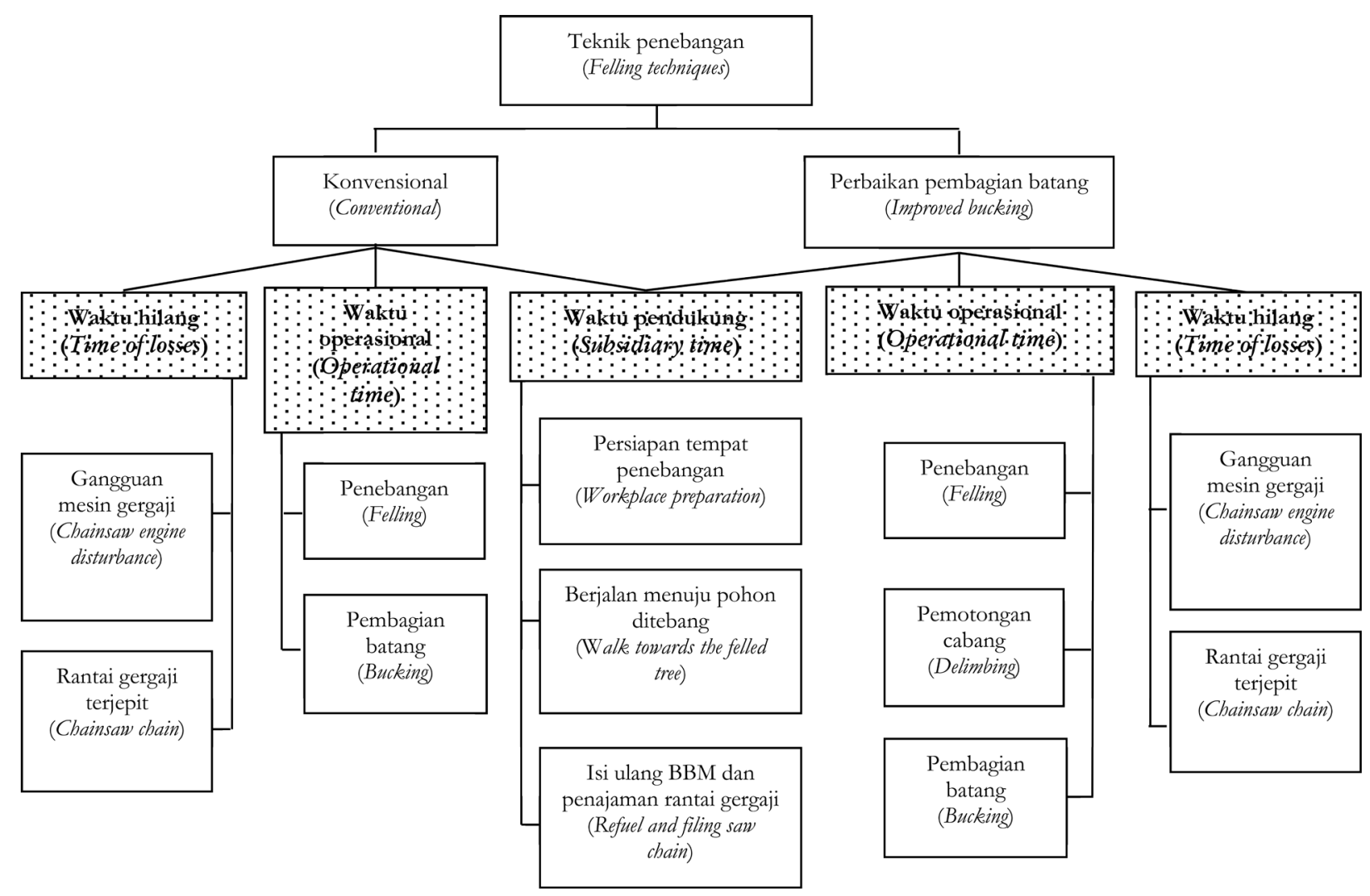

Gambar 3. Prosedur pengukuran waktu penebangan

Figure 3. Felling time measurement procedure 
\& Idris, 2015). Satu tim penebang terdiri atas satu operator chainsaw dan satu orang pembantunya. Waktu penebangan yang diukur meliputi: 1) waktu operasional penebangan, 2) waktu yang diperlukan untuk mendukung pelaksanaan penebangan, dan 3) waktu yang hilang. Secara skematis pengukuran waktu kerja penebangan dapat dilihat pada Gambar 3.

Waktu penebangan mencakup waktu untuk persiapan di tempat penebangan (pembersihan pohon dari gangguan liana dan tumbuhan bawah), membuat takik rebah dan takik balas sampai pohon roboh. Waktu pembagian batang yaitu waktu yang diperlukan untuk pemotongan bagian pangkal dan ujung batang termasuk berjalan dari pangkal hingga ke ujung batang, dan waktu untuk pemotongan cabang-cabang (Budiaman, 2002; Kewilaa \& Tehupeiory, 2015).

Waktu pendukung penebangan meliputi penyetelan chainsaw, penyiapan lokasi, pengikiran rantai gergaji, perjalanan dari dan menuju pohon yang ditebang, pengisian ulang bahan bakar, dan waktu istirahat. Waktu yang hilang merupakan akibat dari kesalahan teknis penebang maupun non teknis, misalnya untuk memperbaiki mesin chainsaw rusak, rantai chainsaw terjepit, dan atau kesalahan menebang pohon yang cacat (Budiaman, 2002). Dalam penelitian ini, waktu istirahat untuk makan siang tidak dimasukkan dalam perhitungan waktu kerja penebangan. Lama waktu kerja diukur menggunakan alat ukur elektronik berupa stop watch dengan tingkat akurasi satu detik.

\section{Pengolahan dan Analisis Data}

\section{Panjang dan diameter batang kayu}

Untuk mengetahui volume batang kayu (log) dilakukan pengukuran panjang $(\mathrm{m})$ dan diameter pangkal dan ujung $(\mathrm{cm})$ dengan meteran gulung. Diameter log rata-rata dihitung dengan rumus menurut Kewilaa dan Tehupeiory, (2015) sebagai berikut:

$$
\begin{aligned}
& D=\frac{D b+D e}{2} \\
& D=\frac{d 1+d 2}{2} . .
\end{aligned}
$$

$D=\frac{d 3+d 4}{2}$

Keterangan (Remarks): $\mathrm{D}=$ Diameter rata-rata (Average diameters, $\mathrm{cm}$ ), $\mathrm{Db}=$ Diameter alas (Diameter of the base, $\mathrm{cm}), \mathrm{De}=$ Diameter ujung $($ Diameter of the top, $\mathrm{cm}), \mathrm{d}_{1}=$ jarak pendek dari diameter pangkal (Short distance of base diameter, $\mathrm{cm}$ ), $\mathrm{d}_{2}=$ jarak panjang dari diameter pangkal (Long distance of base diameter, $\mathrm{cm}), \mathrm{d}_{3}=$ jarak pendek dari diameter ujung (Short distance of top diameter, $\mathrm{cm}), \mathrm{d}_{4}=$ jarak panjang dari diameter ujung (Long distance of top diameter, $\mathrm{cm}$ ).

\section{Volume kayu}

Volume kayu dihitung menggunakan rumus Brereton Metrik, menurut metode pengukuran hutan kayu bulat rimba Indonesia (Direktorat Jenderal Bina Produksi Kehutanan, 2009):

$$
V=\frac{0,7854 \times \mathrm{D}^{2} \times P}{10.000}
$$

Keterangan (Remarks): $\mathrm{V}=$ Volume kayu $\left(\mathrm{m}^{3}\right), 0,7854=$ $1 / 4 \pi, \mathrm{D}=$ Diameter rata-rata (Average diameter, $\mathrm{cm}), \mathrm{P}=$ Panjang (Length, $\mathrm{m})$.

\section{Produktivitas penebangan}

Produktivitas kerja penebangan dihitung menggunakan rumus sebagai berikut (Mujetahid, 2008):

$$
P t p=\frac{V}{W t p}
$$

Keterangan (Remarks): Ptp = Produktivitas penebangan, $\mathrm{m}^{3} / \mathrm{jam}$ (Felling productivity, $\mathrm{m}^{3} /$ hour), $\mathrm{V}=$ Volume $\left(\mathrm{m}^{3}\right)$, Wtp = Waktu kerja penebangan, jam (Working time of felling, hour).

Rata-rata waktu kerja diuji secara statitistik menggunakan program PWSTAT versi 18, dengan hipotesis $\mathrm{H}_{0}: \mu_{1}-\mu_{2}=0$ dan $\mathrm{H}_{1}: \mu_{1}-\mu_{2}$ $\neq 0$. Hubungan antara diameter dan tinggi banir pohon yang ditebang digunakan regresi berganda linear menurut Wijaya (2000) dengan model:

$$
Y=b_{0}+b_{1} X_{1}+b_{2} X_{2}
$$

Keterangan (Remarks): Y = waktu kerja (Working time), $\mathrm{b}_{0}=$ Nilai konstanta (Constant), $\mathrm{b}_{1}$ dan $\mathrm{b}_{2}=$ koefisien regressi (Regression coefficient), $\mathrm{X}_{1}=$ diameter, $\mathrm{X}_{2}=$ tinggi banir (Buttressed beight) 


\section{HASIL DAN PEMBAHASAN}

\section{A. Waktu Kerja Penebangan}

Hasil pengukuran waktu kerja penebangan secara rinci dapat dilihat pada Lampiran 1 dan Lampiran 2 sedangkan rekapitulasinya disajikan pada Tabel 1. Tabel 1 menunjukkan bahwa rata-rata waktu kerja pada metode konvensional (conventional, CV) adalah 14,6 menit/pohon sedangkan pada metode perbaikan pembagian batang (improved bucking method/IBM) sebesar 14,9 menit/pohon. Perbedaan waktu metode perbaikan pembagian batang diakibatkan oleh adanya tambahan waktu untuk pemotongan cabang-cabang pohon hingga bagian ujung batang di atas cabang (BAC) minimal diameter $30 \mathrm{~cm}$. Akan tetapi berdasarkan hasil uji waktu penebangan menggunakan uji Levene (Tabel 2) menunjukkan bahwa nilai $\mathrm{F}_{\text {hitung }}=3,146$ lebih besar dari nilai $\mathrm{F}_{0,05(16,17)}=2,34$ sehingga dapat disimpulkan waktu kerja metode CV tidak berbeda nyata dengan metode IBM.

Hasil penelitian menunjukkan IBM akan menambah waktu kerja lebih lama sebesar rata-rata 0,27 menit/pohon atau sebesar 1,8\% dibandingkan metode CV. Diduga perbedaan waktu penebangan dipengaruhi oleh teknik penebangan, ukuran diameter dan tinggi banir. Pada Lampiran 1 dan Lampiran 2 dapat dilihat bahwa diameter pohon pada metode CV berkisar antara $52-98 \mathrm{~cm}$ dengan rata-rata $66,78 \mathrm{~cm}$ dan tinggi banir $0-150 \mathrm{~cm}$ dengan rata-rata 74,53 $\mathrm{cm}$. Diameter pohon pada IBM berkisar antara $60-108 \mathrm{~cm}$ dengan rata-rata $72,22 \mathrm{~cm}$ dan tinggi banir 0-310 cm dengan rata-rata 98,94 cm.

Penambahan waktu kerja pada metode IBM secara teknis akan berpengaruh pada produktivitas penebangan tetapi dari segi pemanfaatan kayu lebih efisien. Menurut Budiaman (2002) makin besar pohon yang ditebang memerlukan waktu yang makin lama bahkan Behjou et al. (2009) menyatakan selain diameter pohon maka waktu penebangan juga tergantung pada jarak antara pohon ditebang. Dari Lampiran 1 dan Lampiran 2 juga dapat dilihat bahwa waktu yang hilang pada metode CV sedikit lebih besar dibandingkan metode IBM. Waktu hilang metode CV, yang diakibatkan oleh gangguan mesin maupun rantai chainsaw terjepit rata-rata 33,33 detik/pohon dan IBM 29,41 detik/pohon.
Pengamatan di lapangan menunjukkan bahwa potensi waktu hilang umumnya terjadi saat kegiatan pemotongan kayu (cross cutting) baik pada proses pembagian batang ataupun pemotongan cabang. Pada metode CV ukuran diameter kayu yang dipotong pada bagian ujung relatif lebih besar dibandingkan diameter cabang pohon yang roboh. Hasil perhitungan efisiensi pemanfaatan kayu dan produktivitas kerja dapat dilihat pada Lampiran 3 sedangkan rekapitulasinya disajikan pada Tabel 3.

Tabel 3 menunjukkan bahwa rata-tata produktivitas penebangan metode $\mathrm{CV}$ adalah $32,847 \mathrm{~m}^{3} /$ jam dan IBM hanya $27,161 \mathrm{~m}^{3} / \mathrm{jam}$ atau penurunan produktivitas sebesar 17,3\%. Penurunan produktivitas kerja akibat introduksi metode penebangan yang lebih baik adalah hal yang wajar karena penebang masih belum terbiasa sehingga diperlukan cukup waktu untuk menjadi terampil. Beberapa hasil penelitian lain menyatakan bahwa produktivitas penebangan konvensional berkisar antara 31,889-36,240 $\mathrm{m}^{3}$ /jam (Budiaman, 2002; Basari, 2004; Behjou et al., 2009; Elias, 2015; Dulsalam, Sukadaryati, \& Yuniawati, 2018). Penelitian Dulsalam, Sukadaryati, dan Yuniawati, (2018) menunjukkan bahwa introduksi teknik pemanenan kayu berdampak rendah mengakibatkan produktivitasnya menurun dari rata-rata $36,24 \mathrm{~m}^{3} / \mathrm{jam}$ menjadi $32,8 \mathrm{~m}^{3} /$ jam. Produktivitas perbaikan penebangan dengan metode tree length logging berkisar antara 17,679-150,897 $\mathrm{m}^{3} / \mathrm{jam}$ (Idris \& Soenarno, 2015) dan metode pembalakan ramah lingkungan berkisar antara 28,3-36,23 $\mathrm{m}^{3} / \mathrm{jam}$ (Dulsalam et al., 2018; Elias, 2015).

Rata-rata efisiensi pemanfaatan kayu pada metode CV sebesar 85,4\% sedangkan dengan IBM mencapai 93,1\%, atau terjadi kenaikan pemanfaatan kayu sebesar 7,7\%. Peningkatan efisiensi pemanfaatan ini bagi perusahaan sangat menguntungkan karena mendapatkan tambahan volume produksi kayu. Berdasarkan kenyataan bahwa di satu sisi IBM dapat meningkatkan efisiensi pemanfaatan kayu tetapi di sisi lain berdampak menurunnya produktivitas penebang maka penerapannya perlu dilakukan secara bijak.

Hal terpenting dalam implementasi kebijakan IBM adalah penebang perlu mendapatkan kompensasi finansial agar pendapatan yang 
Tabel 1. Waktu kerja penebangan

Table 1. Felling time

\begin{tabular}{|c|c|c|c|c|c|}
\hline \multirow{2}{*}{$\begin{array}{l}\text { Metode penebangan } \\
\text { (Felling methods) }\end{array}$} & \multirow[b]{2}{*}{ Uraian (Description) } & \multicolumn{4}{|c|}{ Waktu kerja penebangan (Felling time), menit/pohon (minutes/tree) } \\
\hline & & $\begin{array}{l}\text { Operasional } \\
\text { (Operational) }\end{array}$ & $\begin{array}{l}\text { Pendukung } \\
\text { (Subsidiary) }\end{array}$ & $\begin{array}{c}\text { Hilang } \\
(\text { Lost })\end{array}$ & $\begin{array}{l}\text { Jumlah } \\
\text { (Total) }\end{array}$ \\
\hline \multirow{4}{*}{$\begin{array}{l}\text { Konvesional } \\
\text { (Conventional) }\end{array}$} & Rata-rata (Average) & 9,3 & 4,2 & 1,0 & 14,6 \\
\hline & Terkecil (Minimum) & 4,7 & 2,7 & 0,0 & 8,1 \\
\hline & Terbesar (Maximum) & 16,7 & 7,1 & 10,0 & 26,5 \\
\hline & $\begin{array}{l}\text { Simpangan baku } \\
\text { (Standard deviation) }\end{array}$ & 3,1 & 1,5 & 3,6 & 5,4 \\
\hline \multirow{4}{*}{$\begin{array}{l}\text { Perbaikan sistem } \\
\text { pembagian batang } \\
\text { (Improved bucking) }\end{array}$} & Rata-rata (Average) & 9,1 & 4,7 & 0,6 & 14,9 \\
\hline & Terkecil (Minimum) & 6,4 & 2,6 & 0,0 & 11,6 \\
\hline & Terbesar (Maximum) & 11,9 & 8,8 & 10,0 & 22,9 \\
\hline & $\begin{array}{l}\text { Simpang baku } \\
\text { (Standard deviation) }\end{array}$ & 1,7 & 2,0 & 3,3 & 3,6 \\
\hline
\end{tabular}

diperoleh minimal sama dengan metode CV. Sebagai gambaran, apabila diasumsikan pada metode CV prestasipenebang sebanyak 15 pohon/ hari dan volume kayu adalah $\pm 5 \mathrm{~m}^{3} /$ pohon maka akan diperoleh produksi kayu bulat $\pm 75 \mathrm{~m}^{3} /$ hari. Apabila upah borongan penebangan adalah $\mathrm{Rp}$ $7.000 / \mathrm{m}^{3}$ maka pendapatan penebang dengan metode CV adalah \pm Rp 525.000/hari tetapi bila menerapkan IBM hanya diperoleh produksi sebanyak $(100-17,3) \%$ x $75= \pm 62,025 \mathrm{~m}^{3} /$ hari sehingga pendapatannya menurun menjadi sekitar Rp 434.175/hari. Agar pendapatan penebang tetap sama seperti sebelumnya (metode CV) maka upah borongan pada IBM harus ditambah minimal menjadi sebesar $7.000+(525.000-$ 434.175) $/ 75=\operatorname{Rp} 8.211 / \mathrm{m}^{3}$ atau dibulatkan menjadi sekitar Rp $8.250 / \mathrm{m}^{3}$.

\section{B. Proporsi Elemen Waktu Operasional Penebangan}

Elemen waktu operasional metode CV terdiri dari serangkaian kegiatan berupa penebangan (felling) yaitu pembuatan takik rebah dan takik balas serta pembagian batang (bucking) batang bebas cabang (BBC). Pada IBM, selain kegiatan seperti pada metode CV terdapat tambahan kegiatan penyiapan log berupa pemotongan pangkal dan ujung batang di atas cabang pertama. Kegiatan pembagian batang metode IBM dilakukan setelah kayu bulat diukur dan diuji oleh tenaga teknis pengelolaan hutan produksi lestari pengujian kayu bulat rimba (Kementerian Kehutanan, 2011). Dalam peraturan tersebut ditegaskan bahwa semua hasil hutan yang berasal

Tabel 2. Hasil analisis ragam total waktu tebang dengan uji t-test Levene Table 2. Analysis results of total felling time with Levene t-test

\begin{tabular}{|c|c|c|c|c|c|c|c|c|c|}
\hline \multirow{3}{*}{$\begin{array}{c}\text { Uraian } \\
\text { (Discription) }\end{array}$} & \multicolumn{2}{|c|}{$\begin{array}{l}\text { Tes Levene untuk } \\
\text { kesetaraan ragam } \\
\text { (Levene's test for equality } \\
\text { of variances) }\end{array}$} & \multicolumn{7}{|c|}{$\begin{array}{l}\text { t-test untuk kesetaraan rata-rata } \\
\quad(\text { t-test for equality of means })\end{array}$} \\
\hline & \multirow{2}{*}{$\begin{array}{l}\text { Fhitung } \\
\text { (Fcal.) }\end{array}$} & \multirow{2}{*}{$\begin{array}{c}\text { Nyata } \\
\text { (Significant). }\end{array}$} & \multirow{2}{*}{$\mathrm{t}$} & \multirow{2}{*}{$\begin{array}{l}\text { Derajat } \\
\text { bebas } \\
\text { (Degree of } \\
\text { freedom })\end{array}$} & \multirow{2}{*}{$\begin{array}{c}\text { Nyata } \\
\text { (Significant) }\end{array}$} & \multirow{2}{*}{$\begin{array}{c}\text { Beda } \\
\text { rata-rata } \\
(\text { Mean } \\
\text { Difference) }\end{array}$} & \multirow{2}{*}{$\begin{array}{c}\text { Perbedaan } \\
\text { kesalahan } \\
\text { baku } \\
\text { (Std. Error } \\
\text { of Difference) }\end{array}$} & \multicolumn{2}{|c|}{$\begin{array}{c}95 \% \text { selang kepercayaan } \\
\text { (Confidence Interval of the } \\
\text { Difference) }\end{array}$} \\
\hline & & & & & & & & $\begin{array}{l}\text { Batas } \\
\text { bawah } \\
\text { (Lower) }\end{array}$ & $\begin{array}{c}\text { Batas } \\
\text { atas } \\
\text { (Upper) }\end{array}$ \\
\hline $\begin{array}{l}\text { Asumsi peubah } \\
\text { sama (Equal variances } \\
\text { assumtion) }\end{array}$ & 3,146 & 0,085 & $-0,180$ & 33 & 0,858 & $-0,27908$ & 1,54879 & $-3,43012$ & 2,87195 \\
\hline $\begin{array}{l}\text { Asumsi peubah } \\
\text { tidak sama (Not equal } \\
\text { variances assumtion) }\end{array}$ & & & $-0,182$ & 31,213 & 0,857 & $-0,27908$ & 1,53537 & $-3,40962$ & 2,85145 \\
\hline
\end{tabular}


Tabel 3. Produktivitas dan efisiensi pemanfaatan kayu Table 3. Productivity and efficiency of timber utilization

\begin{tabular}{|c|c|c|c|c|c|}
\hline $\begin{array}{c}\text { Metode } \\
\text { penebangan } \\
\text { (Felling methods) }\end{array}$ & $\begin{array}{c}\text { Uraian } \\
\text { (Descriptions) }\end{array}$ & $\begin{array}{c}\text { Volume kayu, } \\
\mathrm{m}^{3} / \text { pohon } \\
\text { (Wood volume, } \\
\left.\mathrm{m}^{3} / \text { tree }\right)\end{array}$ & $\begin{array}{l}\text { Waktu penebanganm, } \\
\text { menit/pohon } \\
\text { (Felling time, minutes/tree) }\end{array}$ & $\begin{array}{c}\text { Produktivitas } \\
\text { penebangan, } \mathrm{m}^{3} / \mathrm{jam} \\
\text { (Felling productivity), } \\
\left.\mathrm{m}^{3} / \text { hour }\right)\end{array}$ & $\begin{array}{c}\text { Efisiensi } \\
\text { pemanfaatan kayu, } \\
\mathrm{m}^{3} / \text { pohon } \\
(\text { Wood effciency } \\
\left.\text { utilitation, } \mathrm{m}^{3} / \text { tree }\right) \\
\end{array}$ \\
\hline \multirow{4}{*}{$\begin{array}{l}\text { Konvesional } \\
\text { (Conventional) }\end{array}$} & Rata-rata (Average) & 7,954 & 14.6 & 32.847 & 85,4 \\
\hline & Terkecil (Minimum) & 4,142 & 8.1 & 17.564 & 65,7 \\
\hline & Terbesar (Maximum) & 22,463 & 26.5 & 63.425 & 96,2 \\
\hline & $\begin{array}{l}\text { Simpangan baku } \\
\text { (Standar deviation) }\end{array}$ & 4,905 & 5.9 & 14.145 & 9,2 \\
\hline \multirow{4}{*}{$\begin{array}{l}\text { Perbaikan metode } \\
\text { pembagian batang } \\
\text { (Improved bucking } \\
\text { method) }\end{array}$} & Rata-rata (Average) & 6,387 & 14,9 & 27,161 & 93,1 \\
\hline & Terkecil (Minimum) & 3,064 & 11,6 & 13,585 & 84,4 \\
\hline & Terbesar (Maximum) & 13,499 & 22,9 & 48,356 & 100 \\
\hline & $\begin{array}{l}\text { Simpang baku } \\
\text { (Standar deviation) }\end{array}$ & 2,954 & 3,6 & 11,340 & 5,5 \\
\hline
\end{tabular}

dari hutan negara wajib dilakukan pengukuran dan pengujian oleh petugas yang berwenang/tenaga yang berkualifikasi penguji hasil hutan yaitu oleh tenaga teknis pengelolaan hutan produksi lestari (Ganis PHPL).

Secara rinci jenis pekerjaan dan waktu yang diperlukan untuk kegiatan operasional penebangan disajikan pada Tabel 4. Dari segi teknis, waktu operasional merupakan waktu efektif mesin gergaji rantai karena terkait langsung dengan kebutuhan bahan bakar minyak (BBM) yang dikonsumsi. Makin lama waktu operasional maka makin banyak konsumsi BBM yang akan berpengaruh pada makin besar biaya produksi penebangan. Proporsi waktu operasional penebangan disajikan pada Gambar
4. Gambar 4 memperlihatkan bahwa pada metode $\mathrm{CV}$, proporsi waktu operasional terbesar untuk kegiatan pembuatan takik rebah $(35,37 \%)$ selanjutnya pembagian batang $(33,76 \%)$ dan pembuatan takik balas (29,74\%). Tetapi, pada IBM proporsi terbesar digunakan untuk kegiatan pemotongan cabang $(26,85 \%)$ selanjutnya untuk kegiatan pembuatan takik rebah, takik balas, dan penyiapan log.

1. Proporsi elemen waktu hilang dan pendukung penebangan

Rata-rata jumlah pohon yang ditebang pada metode CV dan IBM masing-masing adalah 9 pohon/ha dengan diameter berkisar antara $51-108 \mathrm{~cm}$ atau rata-rata $72,22 \mathrm{~cm}$ dan

\section{Tabel 4. Jenis pekerjaan dan waktu kerja kegiatan operasional penebangan} Table 4. Working types and time during felling operations

\begin{tabular}{cccc}
\hline No. & \multicolumn{1}{c}{$\begin{array}{c}\text { Jenis pekerjaan } \\
\text { (Type of work) }\end{array}$} & \multicolumn{2}{c}{ Waktu kerja (Working time), menit/pohon (minutes/tree) } \\
\cline { 3 - 4 } & \multicolumn{1}{c}{$\begin{array}{c}\text { Metode konvensional } \\
\text { (Conventional methods) }\end{array}$} & $\begin{array}{c}\text { Metode yang diperbaikan } \\
\text { (Improved methods) }\end{array}$ \\
\hline 1. & Pembuatan takik rebah (Making undercut) & 2,5 & 2,10 \\
2. & Pembuatan takik balas (Making backcut) & 2,1 & 2,03 \\
3. & Penyiapan kayu bulat (Log preparation) & & 2,08 \\
4. & Pemotongan cabang (Branching) & $\left.2,4^{*}\right)$ & 2,45 \\
5. & Pembagian batang (Bucking) & $\left.0,47^{* *}\right)$ \\
6. & Pemotong bagian kayu setelah pengujian \\
& dan pengukuran (Trimming) & 0,1 & 9,1 \\
\hline
\end{tabular}

Keterangan (Remarks): *) = dilakukan di petak tebang (Carried out in the cutting site), $\left.{ }^{* *}\right)=$ dilakukan di TPn setelah pengujian dan pengukuran kayu oleh petugas teknis (Carried out on the TPn after grading scaling by technical officers) 


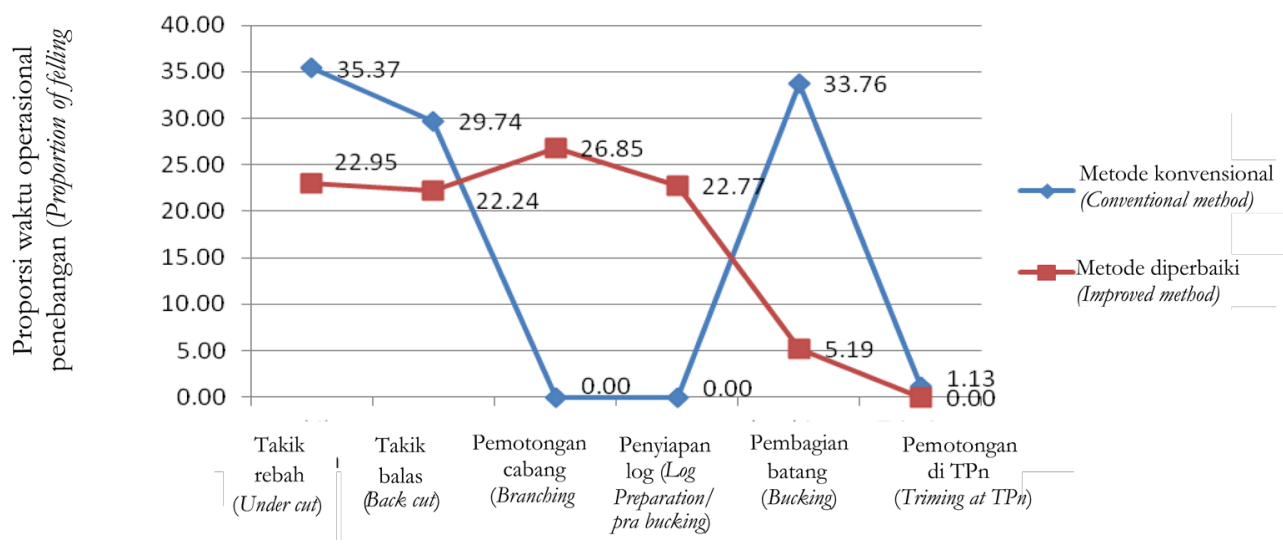

\section{Gambar 4. Proporsi waktu operasional metode CV dan IBM Figure 4. Operational time proportion of $C V$ and IBM}

$52-98 \mathrm{~cm}$ atau rata-rata $66,71 \mathrm{~cm}$. Elemen waktu penebangan yang hilang terdiri dari waktu yang diperlukan untuk perbaikan gangguan mesin chainsaw dan mengatasi hambatan karena rantai chainsaw terjepit. Proporsi elemen waktu kerja penebangan yang hilang disajikan pada Gambar 5.

Gambar 6 menunjukkan bahwa baik pada metode penebangan CV maupun IBM kehilangan waktu kerja karena rantai chainsaw terjepit lebih tinggi dibandingkan akibat gangguan mesin chainsaw. Pengamatan di lapangan menunjukkan bahwa terjadinya rantai chainsaw yang terjepit diakibatkan oleh posisi kerja yang tidak baik dan kurangnya menguasai teknik pemotongan yang benar. Untuk memperkecil potensi resiko rantai chainsaw terjepit dan mengurangi waktu untuk mengatasinya maka posisi operator chainsaw harus nyaman. Pemotongan pertama dimulai dari bagian kayu yang memperoleh tekanan (compression) selanjutkan pada bagian kayu yang mengalami tegangan (tension), sehingga rantai chainsaw tetap tajam dan menggunakan baji agar tidak terjepit (Workers' Compensation Board, 2001; University of New Hampshire, 2001).

Kegiatan pendukung penebangan terdiri dari kegiatan untuk mempersiapkan pohon ditebang, penyetelan gergaji rantai, pengisian ulang BBM, penajaman ulang rantai gergaji dan jalan dari pohon ke pohon ditebang berikutnya. Kegiatan mempersiapkan pohon yang ditebang meliputi penentuan arah rebah pohon, membersihkan kotoran dan liana yang menempel pohon, membersihan tumbuh-tumbuhan di sekitar pohon dan membuat jalur penyelamatan. Proporsi waktu kerja pada kegiatan pendukung penebangan disajikan pada Gambar 6.

Gambar 7 menunjukkan bahwa kegiatan pendukung sebagian besar yaitu $55,31 \%$ pada metode CV dan 58,99\% pada IBM digunakan

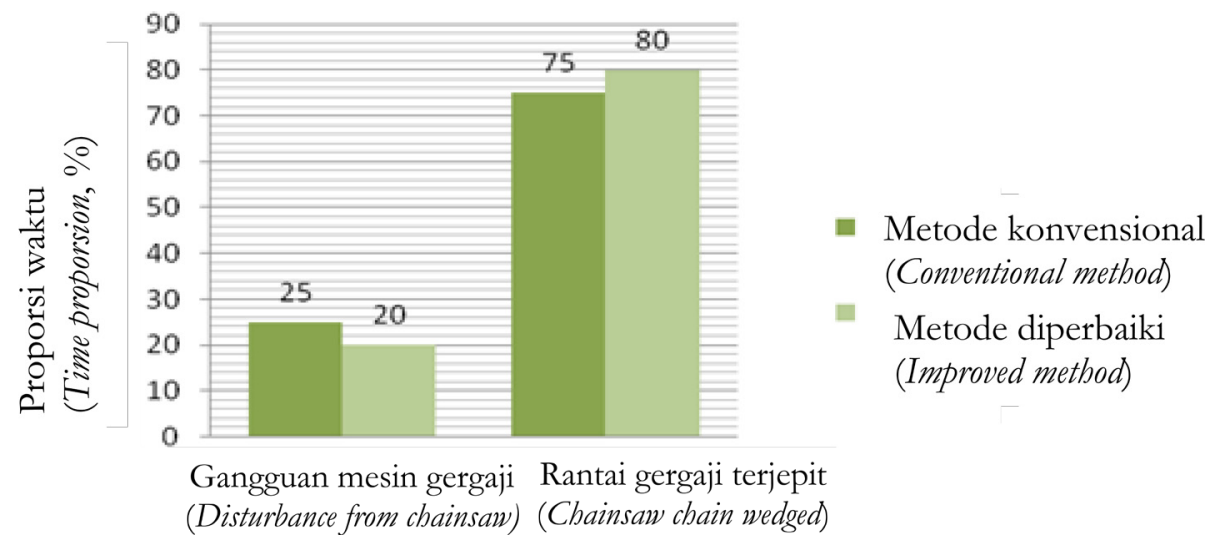

Gambar 5. Proporsi waktu kerja hilang pada kegiatan penebangan pohon Figure 5. Proportion of lost working time on felling activities 


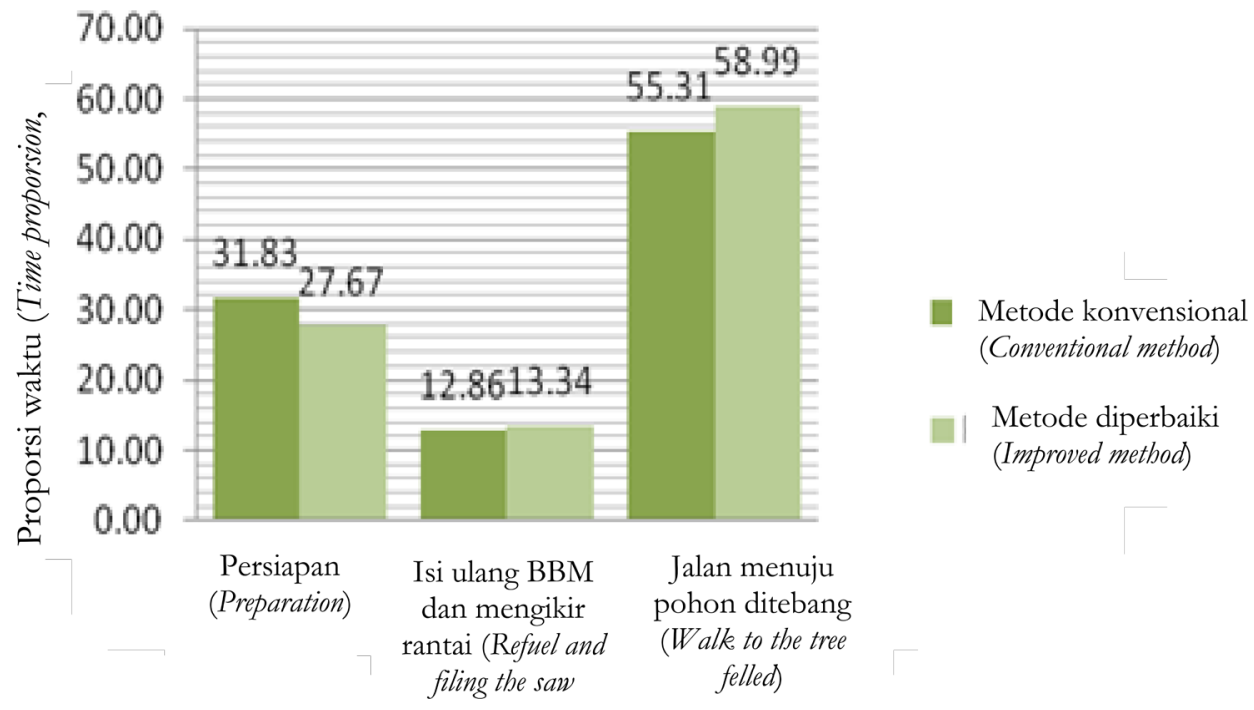

\section{Gambar 6. Proporsi waktu pendukung pada kegiatan penebangan pohon} Figure 6. Proportion of subsidiary working time on felling activities

untuk mencari pohon yang akan ditebang, berjalan dari pohon ke pohon yang akan ditebang berikutnya yang akan ditebang. Hal ini merupakan karakteristik kegiatan penebangan pada sistem tebang pilih dan tanam Indonesia (TPTI) dimana jumlah pohon yang boleh ditebang terbatas dan tersebar secara acak (fragmented) pada hutan alam produksi. Hasil penelitian Budiaman (2002) menunjukkan bahwa waktu untuk mencari dan berjalan dari pohon ke pohon ditebang berikutnya mencapai 31,17\% dari total waktu penebangan.

Secara non teknis kegiatan pendukung sangat penting sebagai prakondisi kelancaran proses penebangan yang aman dan efisien (Applegate, Kartawinata, \& Klassen, 2001; University of New Hampshire, 2001; Holt, 2016). Untuk memperkecil waktu yang dibutuhkan khususnya maka sebelum mulai penebangan, operator chainsaw harus sudah memiliki peta rencana kerja untuk areal yang akan ditebang, lokasi tempat pengumpulan kayu sementara (TPn) termasuk potensi bahaya agar waktu penebangan efisien (Worksave, 2014). Menurut Sist, Dykstra, dan Fimbel (1999) efisiensi waktu penebangan dapat ditingkatkan apabila sebelum memulai penebangan operator chainsaw mempelajari terlebih dahulu keadaan topografi dan informasi posisi pohon yang ada di peta rencana operasi pemanenan kayu (ROPK). Kegiatan ini sangat membantu operator chainsaw untuk memutuskan urutan pohon yang akan ditebang sehingga mengurangi kehilangan waktu kerja.

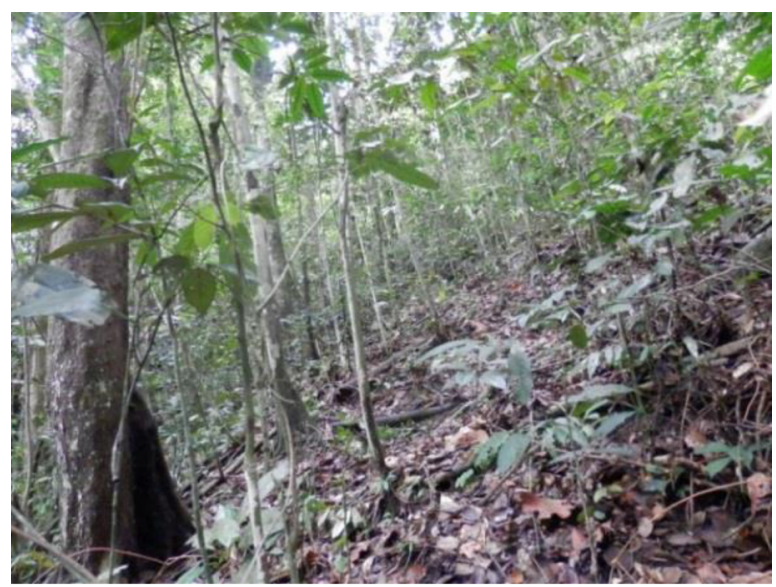

Gambar 7. Kondisi lapangan di areal penebangan Figure 7. Field condition on felling site 

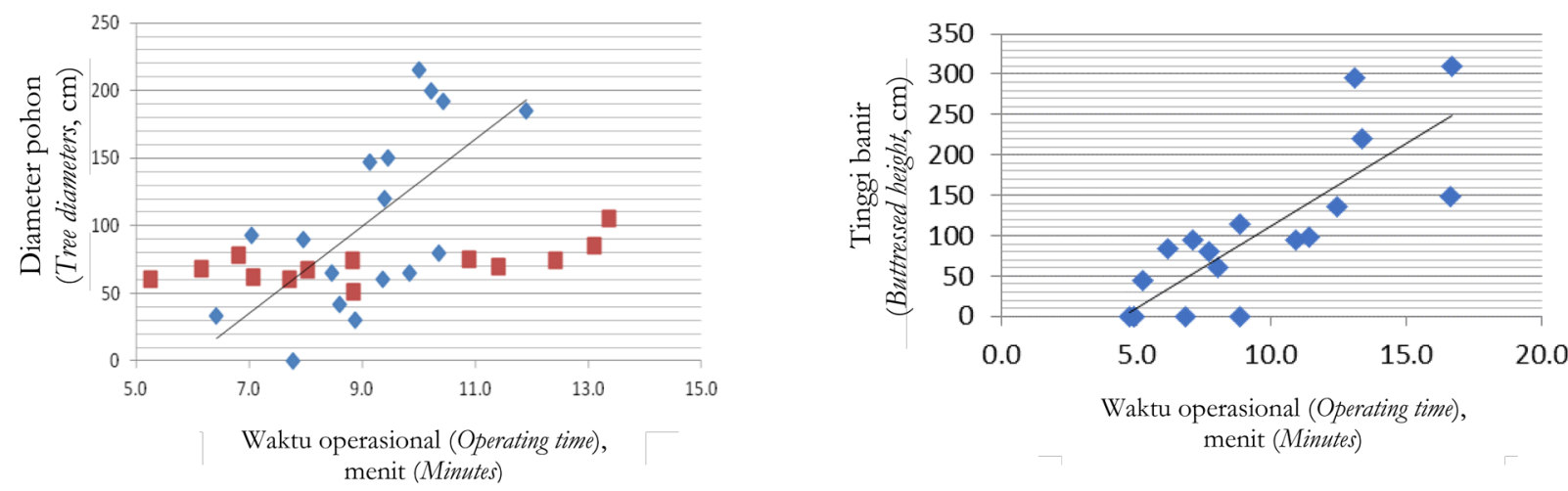

Gambar 8. Hubungan diameter dan tinggi banir dengan waktu operasional pada metode konfensional (CV)

Figure 8. Relationship between diameter and buttress height with operational time on conventional (CV method)

\section{Pengaruh Diameter Pohon dan Tinggi Banir}

Berdasarkan data pada Lampiran 1 diperoleh gambaran bahwa kondisi pohon contoh mempunyai ukuran diameter pohon dan tinggi banir yang berbeda. Kedua variabel tersebut (diameter dan tinggi banir) diduga berpengaruh terhadap waktu yang diperlukan dalam proses penebangan khususnya waktu operasional.

1. Metode penebangan konvensional (CV)

Hasil uji analisis ragam hubungan waktu kerja dengan diameter pohon dan tinggi banir disajikan pada Lampiran 4. Dari Lampiran 4 diketahui koefisien korelasi ganda (Multiple R) sebesar 0,903 yang berarti derajat keeratan hubungan antara variable diameter pohon dan tinggi banir adalah nyata. Besarnya koefisien determinasi $\left(\mathrm{R}_{\text {kuadrat }}=\mathrm{r}^{2}\right)$ adalah 0,815 yang berarti bahwa $81,5 \%$ waktu operasional metode CV ditentukan oleh ukuran diameter dan tinggi banir, sedangkan 18,5\% diduga dipengaruhi oleh kondisi lapangan dan kegiatan persiapan pohon sebelum ditebang. Besarnya koefisien determinasi tinggi banir adalah 0,687 (68,7\%) sehingga pengaruh diameter pohon terhadap waktu operasional penebangan metode CV sebesar $(81,5-68,7)=12,8 \%$.

Dari Lampiran 4 juga dapat diketahui bahwa nilai $\mathrm{F}_{\text {hitung }}=33,124$ lebih besar dari nilai $\mathrm{F}_{0,05(2,15)}=3,68$. Dengan demikian dapat disimpulkan bahwa hubungan antara variabel diameter pohon dan variabel tinggi banir dengan waktu operasional penebangan dalam persamaan $\mathrm{Y}=-0,976+0,025 \mathrm{X}_{1}+0,108$ $\mathrm{X}_{2}$ bersifat nyata, dimana $\mathrm{X}_{1}$ adalah diameter

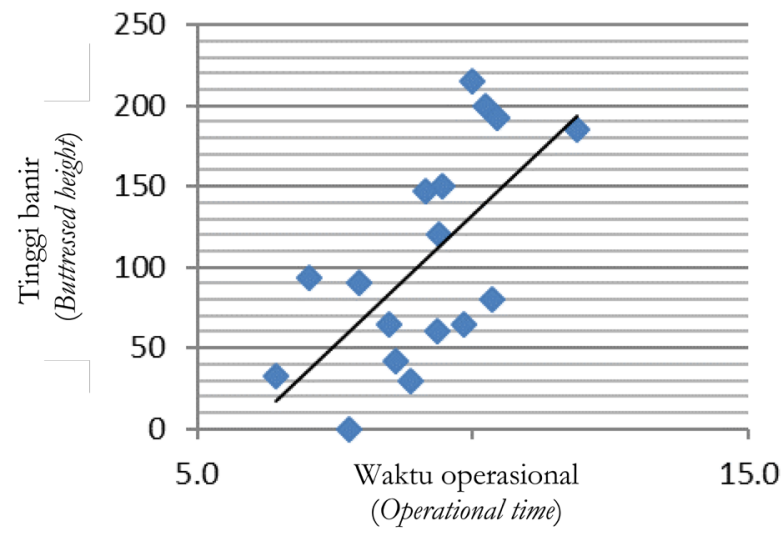

Gambar 9. Hubungan diameter dan tinggi banir dengan waktu opersional pada IBM Figure 9. Relationship between diameter and buttress height with operational time on IBM 

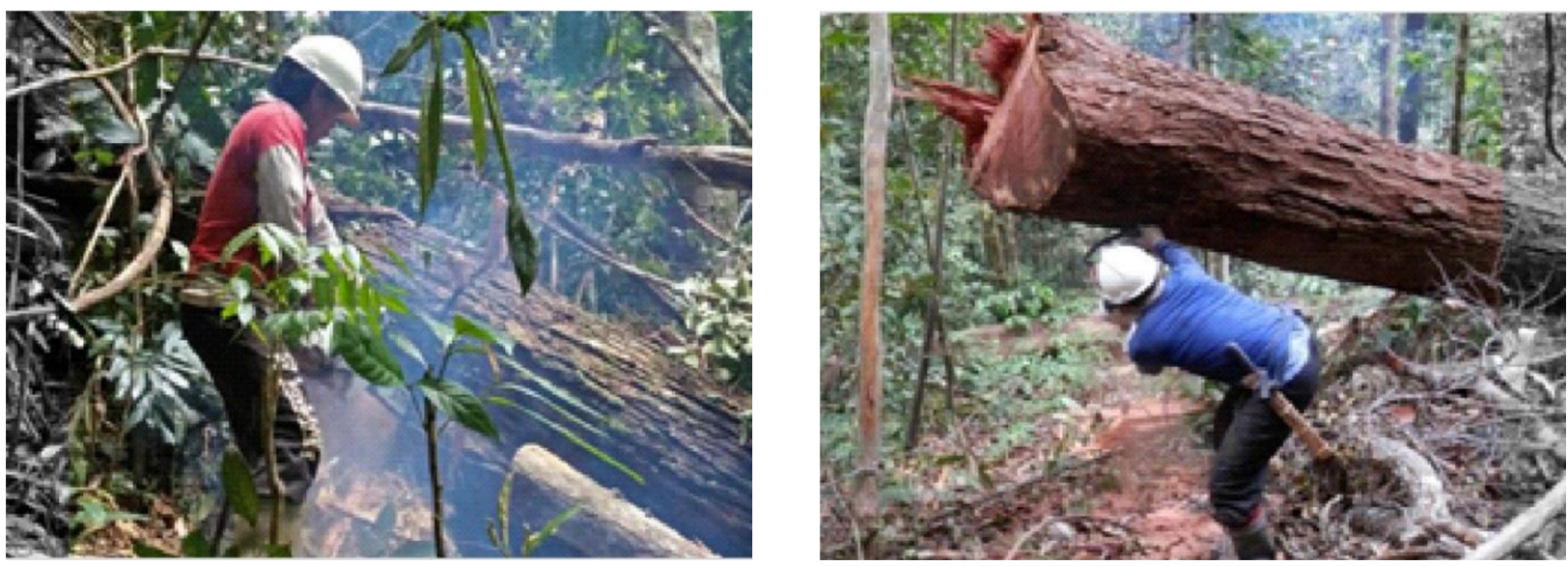

Gambar 10. Kondisi batang dan cabang pohon setelah ditebang Figure 10. Condition of tree trunks and branches after felling

pohon $(\mathrm{cm})$ dan $\mathrm{X}_{2}$ adalah tinggi banir $(\mathrm{cm})$. Secara terpisah hubungan diameter pohon dan tinggi banir terhadap waktu operasional penebangan disajikan secara grafik pada Gambar 8.

2. Metode penebangan dengan perbaikan metode pembagian batang (IBM)

Hasil uji analisis ragam hubungan waktu operasional penebangan IBM dengan diameter pohon dan tinggibanirdapatdilihat padaLampiran 5. Dari Lampiran 5 juga dapat diketahui bahwa nilai $\mathrm{F}_{\text {hitung }}=11,277$ (lebih besar dari nilai $\mathrm{F}_{0,052 \text {, }}$ $\left.{ }_{15)}=3,68\right)$ sehingga dapat disimpulkan bahwa hubungan antara variabel diameter pohon dan variabel tinggi banir dengan waktu operasional penebangan dalam persamaan $\mathrm{Y}=4,487+$ $0,053 \mathrm{X}_{1}+0,010 \mathrm{X}_{2}$ bersifat nyata, dimana $\mathrm{X}_{1}$ adalah diameter pohon $(\mathrm{cm})$ dan $\mathrm{X}_{2}$ adalah tinggi banir pohon $(\mathrm{cm})$. Secara terpisah hubungan diameter pohon dan tinggi banir terhadap waktu operasional penebangan disajikan secara grafik pada Gambar 9.

Waktu hilang metode CV maupun IBM terjadinya akibat mesin gergaji rantai terjepit pada waktu pekerjaan pemotongan pada bagian pangkal batang, bagian ujung batang (toping off), dan/atau cabang pohon (branching). Potensi resiko rantai chainsaw terjepit terjadi akibat kondisi batang pohon atau cabang pohon yang tidak ideal sehingga posisi kerja operator chainsaw menjadi tidak leluasa untuk melakukan Teknik pemotongan secara benar, sebagaimana contoh pada Gambar 10.

\section{KESIMPULAN DAN SARAN}

\section{A. Kesimpulan}

Perbaikan metode pembagian batang (IBM) dalam proses penebangan pohon dapat meningkatkan efisiensi pemanfaatan dibandingkan metode konvensional (CV). Efisiensi pemanfaatan kayu IBM meningkat menjadi 93,1\% dibandingkan metode CV sebesar $85,4 \%$. Waktu penebangan metode CV rata-rata adalah 14,6 menit/pohon sedangkan IBM sebesar 14,9 menit/pohon. Produktivitas penebangan rata-rata IBM adalah 27,161 $\mathrm{m}^{3}$ / jam dan metode konvensional sebesar 32,847 $\mathrm{m}^{3} / \mathrm{jam}$. Menurunnya produktivitas penebangan IBM disebabkan oleh adanya tambahan kegiatan pemotongan cabang (branching) di petak tebang.

\section{B. Saran}

Untuk meningkatkan produktivitas penebangan sebaiknya operator chainsaw mempelajari secara cermat peta rencana operasional pemanenan kayu sehingga pelaksanaan penebangan dapat dilakukan secara sistematis dan efisien. Operator chainsaw perlu mendapatkan kebijakan perbaikan upah borongan sebagai kompensasi menurunnya produktivitas kerja mereka.

\section{UCAPAN TERIMA KASIH}

Ucapan terima kasih disampaikan kepada pimpinan IUPHHK-HA PT. Dwima Jaya Utama khususnya Bapak Haris Yuniawan dan Bisri 
Mustofa yang telah membantu mengkoordinir pelaksanaan penelitian di lapangan hingga dapat berjalan lancar, juga ucapan terima kasih disampaikan kepada Bapak Ir. Zakaria Basari, B.ScF atas bantuannya selama pengumpulan data.

\section{KONTRIBUSI PENULIS}

Ide, desain dan rancangan percobaan dilakukan oleh SOE. Pengambilan data dilakukan oleh SOE. Analisis data dilakukan oleh SOE dan penulisan manuskrip dilakukan oleh SOE. Perbaikan dan finalisasi manuskrip dilakukan oleh SOE dan $\mathrm{YN}$.

\section{DAFTAR PUSTAKA}

Abbasi, E., Lotfalian, M., \& Hosseini, S. A. O. (2013). Productivity and cost of tree felling crew with a chainsaw in Caspian forests. Journal of Biodiversity and Environmental Sciences, 3(9), 90-97.

Astana, S., Soenarno, \& Endom, W. (2015). Potensi penerimaan negara bukan pajak dari limbah pemanenan di hutan alam dan hutan tanaman. Jurnal Penelitian dan Pengembangan Sosial dan Ekonomi Kehutanan, 12(3), 227-243.

Basari, Z. (2004). Analisa biaya pemanenan kayu bulat sistem kemitraan HPH-Koperasi Desa di Kalimantan Tengah. Jurnal Penelitian Hasil Hutan, 22(2), 113-122.

Behjou, F. K., Majnounian, B., Dvořák, J., Namiranian, M., Saeed, A., \& Feghhi, J. (2009). Productivity and cost of manual felling with a chainsaw in Caspian forests. Journal of Forest Science, 55(2), 96-100.

Budiaman, A. (2002). Waktu kerja dan produktivitas penebangan kayu penuh (whole tree) pada pengusahaan hutan alam. Jurnal Teknologi Hasil Hutan, 15(2), 1-6.

Direktorat Jenderal Bina Produksi Kehutanan (2009). Peraturan Direktur Jenderal Bina Produksi Kehutanan. Nomor: P.14/ VI-BIKPHH/2009 tentang metode pengukuran dan tabel isi kayu bulat rimba Indonesia. Jakarta.
Dulsalam, Sukadaryati, \& Yuniawati. (2018). Produktivitas, efisiensi dan biaya penebangan silvikultur intensif pada satu perusahaan di Kalimantan Timur. Jurnal Penelitian Hasil Hutan, 36(1), 1-12.

Elias, Applegate, G., Kartawinata, K., \& Klassen, A. (2001). Pedoman reduced impact logging Indonesia. Bogor: Center for International Forestry Research.

Elias. (2015). Pengertian dan perkembangan IPTEK pemanenankayu. Bogor: Fakultas Kehutanan, Institut Pertanian Bogor.

Elias. (2016). Penerapan reduced impact logging dalam rangka reformasi eksploitasi butan dan korupsi dalam pengelolaan butan alam tropika Indonesia. Orasi Ilmiah Guru Besar IPB. Bogor: Fakultas Kehutanan, Institut Pertanian Bogor.

Enters, T. (2001). Trash or treasure? logging and mill residues in Asia and the Pacific. Bangkok.

Forestry Training Centre Incorporated. (2010). Course in reduced impact logging: Chainsaw use, safety practices \& directional tree felling techniques. Guyana.

Garland, J., \& Jackson, D. (1997). Felling and bucking techniques for woodland owners. Oregon.

Ghajar, I., \& Naja, A. (2012). Forest policy and economics evaluation of harvesting methods for sustainable forest management (SFM) using the analytical network process (ANP). Journal of Forest Policy and Economics, 21, 81-91.

Greulich, F., Hanley, D., McNeel, J., \& Baumgartner, D. (1999). A primer for timber harvesting. Washington: Washington State University.

Holt, G. (2016). How to cut down a tree: safe and effective tree felling, limbing and Bucking. Alaska.

Idris, M. M., \& Soenarno. (2015). Penerapan metode tree length logging skala operasional di areal teknik silvikultur intensif (Studi kasus di PT Parakanca Timber Provinsi Kalimantan Timur). Penelitian Hasil Hutan, 33(1), 19-34. 
Kewilaa, B., \& Tehupeiory, A. (2015). Effects of working time and the volume and weight of timber on productivity of log loader Caterpillar type $966 \mathrm{~F}$ and WL 980 C. Wood Research Journal, 6(1), 1-6.

Matangaran, J., Partiani, T., \& Purnamasari, D. (2013). Faktor eksploitasi dan kuantifikasi limbah kayu dalam rangka peningkatan efisiensi pemanenan hutan alam. Bumi Lestari, 13(2), 384-393.

Mujetahid, A. (2008). Produktivitas penebangan pada hutan jati (Tectona Grandis). Jurnal Perennial, 5(1), 53-58.

Ruslim, Y., \& Gunawan. (2008). Faktor eksploitasi dan faktor pengamanan pada kegiatan penebangan sistem tebang pilih tanam Indonesia ITPTI) di HPH PT. Sarmiento Parakantja Timber Kalimantan Tengah. Jurnal Kehutanan Tropika Humida, 1(1), 95108.

Sist, P., Dykstra, D., \& Fimbel, R. (1999). Pedoman pembalakan berdampak rendah untuk butan dipterocarpa lahan rendab dan berbukit di Indonesia. Bogor.

Soenarno, Endom, W., Basari, Z., Suhartana, S., Dulsalam, \& Yuniawati. (2016). Faktor eksploitasi hutan di Sub Region Kalimantan Timur. Jurnal Penelitian Hasil Hutan, 34(4), 335-348.
Soenarno, \& Idris, M. M. (2015). Pedoman teknis di tree length logging butan alam produksi lahan kering. Bogor: Pusat Penelitian dan Pengembangan Hasil Hutan.

Surat Keputusan Menteri Kehutanan. (2011). Pengukuran dan pengujian hasil butan (SK Kemenhut No. P.45/Menhut-II/2011). Jakarta: Kementerian Kehutanan.

University of New Hampshire. (2001). Safe timber harvesting. University of New Hampshire.

Ward, E. (2011). Chain saws safety, operation, tree felling techniques. Manhattan.

Wijaya. (2000). Analisis statistik dengan program SPSS 10.0. Bandung: Alfabeta, Bandung.

Workers' Compensation Board. (2001). Practical methodsforfallingandbuckingtimbersafely (2001st ed.). Columbia: Workers' Compensation Board of British Columbia.

Worksave, N. Z. (2014). Safe manual tree felling. Wellington. Diakses dari https://www. arbinnovations.co.nz/tree-services pada tanggal 10 Desember 2018. 


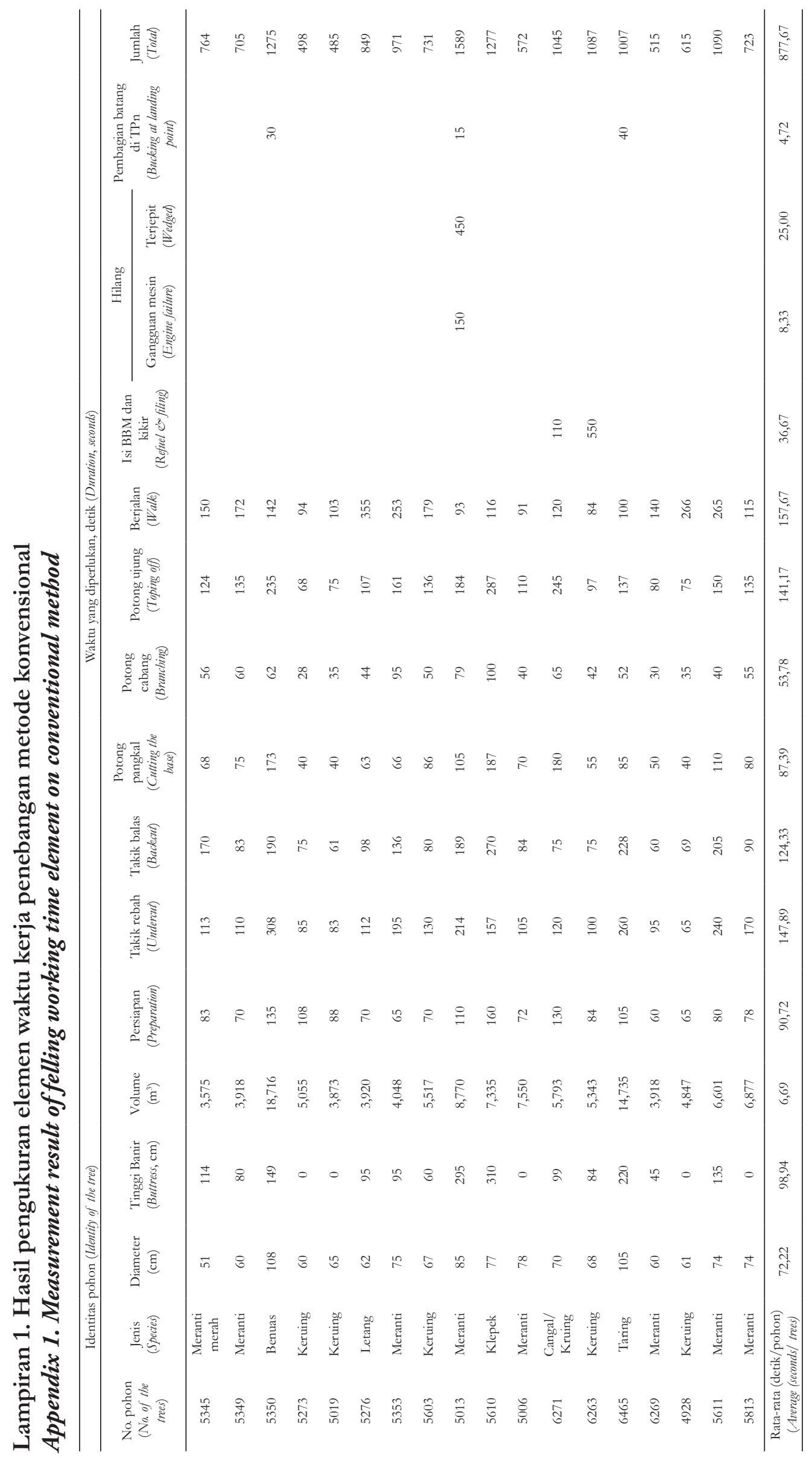


jURNAL Penelitian Hasil Hutan Vol. 37 No. 1, Maret 2019: 13-32

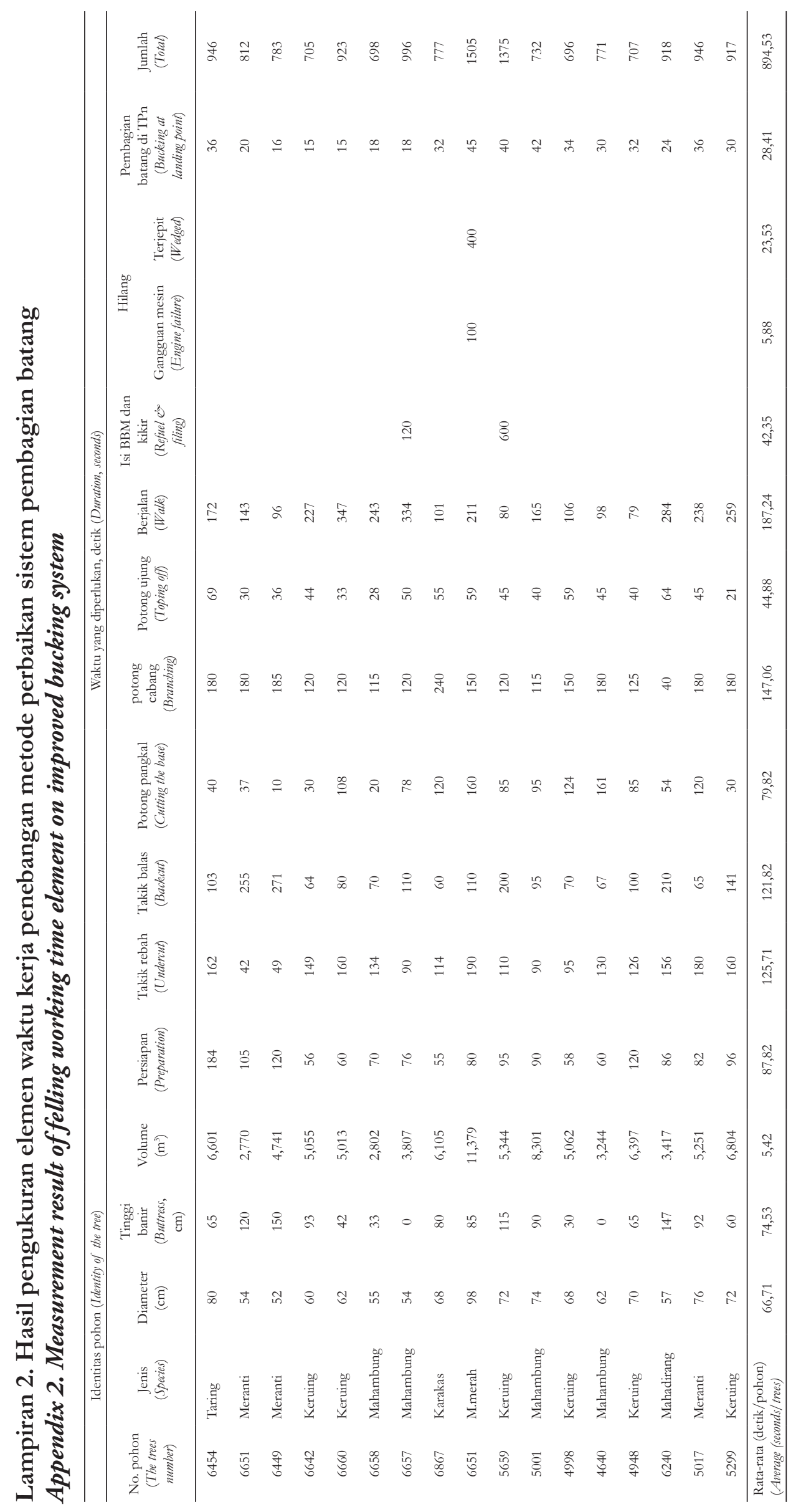




\section{Lampiran 3. Perhitungan produktivitas dan efisiensi pemanfaatan kayu} Appendix 3. Productivity and efficiency calculation of timber utilization

\begin{tabular}{|c|c|c|c|c|c|c|c|c|}
\hline \multicolumn{5}{|c|}{ Identitas pohon (Identity of the tree) } & \multirow{2}{*}{$\begin{array}{c}\text { Kayu } \\
\text { dimanfaatkan } \\
\left(\text { Utilized wood, } \mathrm{m}^{3}\right)\end{array}$} & \multirow{2}{*}{$\begin{array}{l}\text { Waktu diperlukan, } \\
\text { detik } \\
\text { (Time required, } \\
\text { seconds) }\end{array}$} & \multirow{2}{*}{$\begin{array}{c}\text { Produktivita, } \\
\mathrm{m}^{3} / \text { jam } \\
\text { (Productivity, } \\
\left.\mathrm{m}^{3} / \text { tree }\right) \\
\end{array}$} & \multirow{2}{*}{$\begin{array}{c}\text { Efisiensi } \\
\text { pemanfaatan kayu } \\
\text { (Wood utilized } \\
\text { efficiency, \%) } \\
\end{array}$} \\
\hline $\begin{array}{l}\text { No. pohon } \\
\text { (The trees number) }\end{array}$ & $\begin{array}{l}\text { Jenis pohon } \\
\text { (Tree species) }\end{array}$ & $\begin{array}{l}\text { Diameter, } \\
\mathrm{cm}\end{array}$ & $\begin{array}{c}\text { Banir } \\
\text { (Buttress, cm) }\end{array}$ & Volume $\left(\mathrm{m}^{3}\right)$ & & & & \\
\hline \multicolumn{9}{|c|}{ Metode konvensional (Conventional method) } \\
\hline 6454 & Taring/meranti & 80 & 65 & 6,601 & 7,105 & 946 & 25,120 & 92,90 \\
\hline 6651 & Meranti & 54 & 120 & 2,770 & 2,770 & 812 & 12,280 & 99,98 \\
\hline 6449 & Meranti & 52 & 150 & 4,741 & 4,744 & 783 & 21,799 & 99,95 \\
\hline 6642 & Keruing & 60 & 93 & 5,055 & 5,221 & 705 & 25,815 & 96,83 \\
\hline 6660 & Keruing & 62 & 42 & 5,013 & 5,377 & 923 & 19,552 & 93,24 \\
\hline 6658 & Mahambung & 55 & 33 & 2,802 & 3,319 & 698 & 14,451 & 84,42 \\
\hline 6657 & Mahambung & 54 & 0 & 3,807 & 3,987 & 996 & 13,761 & 95,48 \\
\hline 6867 & Karakas & 68 & 80 & 6,105 & 6,444 & 777 & 28,285 & 94,74 \\
\hline 6651 & M.merah & 98 & 85 & 11,379 & 13,322 & 1505 & 27,219 & 85,41 \\
\hline 5659 & Keruing & 72 & 115 & 5,344 & 5,485 & 1375 & 13,992 & 97,43 \\
\hline 5001 & Mahambung & 74 & 90 & 8,301 & 8,466 & 732 & 40,825 & 98,06 \\
\hline 4998 & Keruing & 68 & 30 & 5,062 & 5,492 & 696 & 26,183 & 92,17 \\
\hline 4640 & Mahambung & 62 & 0 & 3,244 & 3,728 & 771 & 15,148 & 87,02 \\
\hline 4948 & Keruing & 70 & 65 & 6,397 & 7,251 & 707 & 32,573 & 88,22 \\
\hline 6240 & Mahadirang & 57 & 147 & 3,417 & 4,013 & 918 & 13,402 & 85,16 \\
\hline 5017 & Meranti & 76 & 92 & 5,251 & 5,252 & 946 & 19,981 & 99,98 \\
\hline \multirow[t]{2}{*}{5299} & Keruing & 72 & 60 & 6,804 & 7,402 & 917 & 26,712 & 91,92 \\
\hline & $\begin{array}{c}\text { Rata-rata } \\
\text { (Average) }\end{array}$ & 66,71 & 74,53 & 5,2 & 5,846 & $\begin{array}{c}894.529 \\
(14,9 \text { menit }) \\
\end{array}$ & 22,182 & 93,113 \\
\hline \multicolumn{9}{|c|}{ Metode Perbaikan sistim pembagian batang (Improved bucking system mothod) } \\
\hline 5345 & Meranti merah & 51 & 114 & 3,575 & 4,065 & 764 & 16,847 & 87,95 \\
\hline 5349 & Meranti & 60 & 80 & 3,918 & 5,965 & 705 & 20,007 & 65,68 \\
\hline 5350 & Benuas & 108 & 149 & 18,716 & 22,463 & 1275 & 52,846 & 83,32 \\
\hline 5273 & Keruing & 60 & 0 & 5,055 & 5,793 & 498 & 36,545 & 87,27 \\
\hline 5019 & Keruing & 65 & 0 & 3,873 & 4,562 & 485 & 28,745 & 84,89 \\
\hline 5276 & Letang & 62 & 95 & 3,920 & 4,142 & 849 & 16,623 & 94,64 \\
\hline 5353 & Meranti & 75 & 95 & 4,048 & 5,507 & 971 & 15,007 & 73,50 \\
\hline 5603 & Keruing & 67 & 60 & 5,517 & 5,871 & 731 & 27,169 & 93,97 \\
\hline 5013 & Meranti & 85 & 295 & 8,770 & 12,420 & 1589 & 19,868 & 70,61 \\
\hline 5610 & Klepek & 77 & 310 & 7,335 & 9,966 & 1277 & 20,678 & 73,60 \\
\hline 5006 & Meranti & 78 & 0 & 7,550 & 8,359 & 572 & 47,514 & 90,32 \\
\hline 6271 & Cangal/Kruing & 70 & 99 & 5,793 & 6,024 & 1045 & 19,955 & 96,16 \\
\hline 6263 & Keruing & 68 & 84 & 5,343 & 6,037 & 1087 & 17,695 & 88,50 \\
\hline 6465 & Taring & 105 & 220 & 14,735 & 17,522 & 1007 & 52,678 & 84,10 \\
\hline 6269 & Meranti & 60 & 45 & 3,918 & 4,314 & 515 & 27,389 & 90,83 \\
\hline 4928 & Keruing & 61 & 0 & 4,847 & 5,512 & 615 & 28,370 & 87,93 \\
\hline 5611 & Meranti & 74 & 135 & 6,601 & 7,153 & 1090 & 21,803 & 92,29 \\
\hline \multirow[t]{2}{*}{5813} & Meranti & 74 & 0 & 6,877 & 7,495 & 723 & 34,241 & 91,75 \\
\hline & $\begin{array}{l}\text { Rata-rata } \\
\text { (Average) }\end{array}$ & 72,22 & 98,94 & 6,69 & 7,954 & $\begin{array}{c}877,667 \\
(14,6 \text { menit }) \\
\end{array}$ & 27,999 & 85,407 \\
\hline
\end{tabular}


jURNAL Penelitian Hasil Hutan Vol. 37 No. 1, Maret 2019: 13-32

Lampiran 4. Analisis regresi berganda waktu operasional pada metode konvensional (CV) Appendix 4. Multiple regression analysis of operational time on conventional CV methods

\begin{tabular}{ccccc}
\hline \multicolumn{5}{c}{ Ringkasan model (Model Summary) } \\
\hline Model & $\mathrm{R}$ & $\begin{array}{c}\text { R kuadrat } \\
(\mathrm{R} \text { Square })\end{array}$ & $\begin{array}{c}\mathrm{R} \text { kuadrat penyesuaian } \\
(\text { Adjusted R S quare })\end{array}$ & $\begin{array}{c}\text { Kesalahan baku pendugaan } \\
\text { (Std. error of the Estimate) }\end{array}$ \\
\hline 1 & $0,812^{\mathrm{a}}$ & 0,660 & 0,637 & 1,01957 \\
2 & $0,870^{\mathrm{b}}$ & 0,757 & 0,723 & 0,89108 \\
\hline
\end{tabular}

Keterangan (Remarks): a. Penduga (Predictors): Tetap (Constant), Diameter; b. Penduga (Predictors): Tetap (Constant),

Diameter, Tinggi banir (Buttress height); c. Peubah bergantung (Dependent variable): Waktu operasional penebangan (Operational felling time)

\begin{tabular}{lccccc}
\hline \multicolumn{5}{c}{ Analisis ragam (Analysisi of variance) } \\
\hline $\begin{array}{c}\text { Sumber keragaman } \\
\text { (Sources of variance) }\end{array}$ & $\begin{array}{c}\text { Jumlah kuadrat } \\
(\text { Sum of Squares) }\end{array}$ & $\begin{array}{c}\text { Derajat bebas } \\
(\text { Degree of freedom })\end{array}$ & $\begin{array}{c}\text { Kuadrat rata-rata } \\
(\text { Mean Square })\end{array}$ & $\begin{array}{c}\mathrm{F}_{\text {hitung }} \\
\left(F_{\text {calculation }}\right)\end{array}$ & $\begin{array}{c}\text { Nyata } \\
\text { (Significance })\end{array}$ \\
\hline Regresi (Regression) & 34,699 & 2 & 17,350 & 21,850 & $0,000^{a}$ \\
Galat (Residual) & 11,116 & 14 & 0,794 & & \\
Jumlah (Total) & 45,815 & 16 & & & \\
\hline
\end{tabular}

Keterangan (Remarks): a. Penduga (Predictors): Tetap (Constant), Banir pohon (Buttresed, Diameter pohon (Tree diameters)

Koefisien (Coefficients) ${ }^{a}$

\begin{tabular}{|c|c|c|c|c|c|}
\hline \multicolumn{6}{|c|}{ Koefisien (Coefficients) ${ }^{\mathrm{a}}$} \\
\hline \multirow{2}{*}{ Model } & \multicolumn{2}{|c|}{$\begin{array}{c}\text { Koefisien tidak baku } \\
\text { (Unstandardized Coefficients) }\end{array}$} & \multirow{2}{*}{$\begin{array}{c}\text { Koefisien baku } \\
\text { (Standardized Coefficients) } \\
\text { Beta }\end{array}$} & \multirow{2}{*}{$\mathrm{t}$} & \multirow{2}{*}{$\begin{array}{c}\text { Nyata } \\
\text { (Significance) }\end{array}$} \\
\hline & B & $\begin{array}{c}\text { Kesalahan baku } \\
\text { (Std. Error) }\end{array}$ & & & \\
\hline Bilangan tetap (Constant) & 1,155 & 1,333 & & 0,866 & 0,401 \\
\hline $\begin{array}{l}\text { Tinggi banir } \\
\text { (Buttress height, } \mathrm{X}_{1} \text { ) }\end{array}$ & 0,116 & 0,019 & 0,810 & 6,156 & 0,000 \\
\hline Diameter, $\left(\mathrm{X}_{2}\right)$ & $-0,012$ & 0,005 & $-0,313$ & $-2,374$ & 0,032 \\
\hline
\end{tabular}

Keterangan (Remarks): a. Peubah bergantung (Dependent variable): Waktu operasional penebangan (Operational felling time) 
Lampiran 5. Analisis regresi berganda waktu operasional pada metode perbaikan bucking (IBM)

Appendix 5. Multiple regression analysis of operational time on improved bucking methods (IBM)

\begin{tabular}{ccccc}
\hline \multicolumn{5}{c}{ Ringkasan model (Model Summary) } \\
\hline Model & $\mathrm{R}$ & $\begin{array}{c}\text { R kuadrat } \\
(\mathrm{R} \text { S quare })\end{array}$ & $\begin{array}{c}\text { R kuadrat penyesuaian } \\
\text { (Adjusted R Square })\end{array}$ & $\begin{array}{c}\text { Kesalahan baku pendugaan } \\
\text { (Std. error of the estimate) }\end{array}$ \\
\hline 1 & $0,829^{\mathrm{a}}$ & 0,687 & 0,667 & 2,24368 \\
2 & $0,903^{\mathrm{b}}$ & 0,815 & 0,791 & 1,77891 \\
\hline
\end{tabular}

Keterangan (Remarks): a. Penduga (Predictors): Tetap (Constant), Diameter; Penduga (Predictors): Tetap (Constant), Diameter, Tinggi banir (Buttress height); c. Peubah bergantung (Dependent variable): Waktu operasional penebangan (Operational felling time)

\begin{tabular}{lccccc}
\hline \multicolumn{5}{c}{ Analisis ragam (Analysisis of variance) } \\
\hline $\begin{array}{c}\text { Sumber keragaman } \\
\text { (Sources of variance) }\end{array}$ & $\begin{array}{c}\text { Jumlah kuadrat } \\
\text { (Sum of Squares) }\end{array}$ & $\begin{array}{c}\text { Derajat bebas } \\
(\text { Degree of freedom })\end{array}$ & $\begin{array}{c}\text { Kuadrat rata-rata } \\
(\text { Mean Square })\end{array}$ & $\begin{array}{c}\mathrm{F}_{\text {hitung }} \\
\left(\mathrm{F}_{\text {calcultion }}\right)\end{array}$ & $\begin{array}{c}\text { Nyata } \\
\text { (Significance) }\end{array}$ \\
\hline Regresi (Regression) & 209,643 & 2 & 104,822 & 33,124 & $0,000^{a}$ \\
Galat (Residual) & 47,468 & 15 & 3,165 & & \\
Jumlah (Total) & 257,111 & 17 & & & \\
\hline
\end{tabular}

Keterangan (Remarks): a. Penduga (Predictors): Tetap (Constant), Banir pohon (Buttressed), Diameter pohon (Tree diameters)

\begin{tabular}{|c|c|c|c|c|c|}
\hline \multicolumn{6}{|c|}{ Koefisiens (Coefficiens) ${ }^{\mathrm{a}}$} \\
\hline \multirow{2}{*}{ Model } & \multicolumn{2}{|c|}{$\begin{array}{c}\text { Koefisien tidak baku } \\
\text { (Unstandardized Coefficients) }\end{array}$} & \multirow{2}{*}{$\begin{array}{c}\text { Koefisien baku } \\
\text { (Standardized Coefficients) }\end{array}$} & \multirow{2}{*}{$\mathrm{t}$} & \multirow{2}{*}{$\begin{array}{c}\text { Nyata } \\
\text { (Significance) }\end{array}$} \\
\hline & B & $\begin{array}{l}\text { Kesalahan baku } \\
\quad \text { (Std. Error) }\end{array}$ & & & \\
\hline Bilangan tetap (Constant) & $-0,976$ & 2,240 & & $-0,436$ & 0,669 \\
\hline $\begin{array}{l}\text { Tinggi banir } \\
\text { (Buttress height, } \mathrm{X}_{1} \text { ) }\end{array}$ & 0,025 & 0,005 & 0,615 & 4,759 & 0,000 \\
\hline Diameter $\left(\mathrm{X}_{2}\right)$ & 0,108 & 0,034 & 0,418 & 3,233 & 0,006 \\
\hline
\end{tabular}

Keterangan (Remarks): a. Peubah bergantung (Dependent variable): Waktu operasional penebangan (Operational felling time) 